\title{
EXPLORING UNIVERSITY-TO-COLLEGE TRANSFER IN ONTARIO: A QUALITATIVE STUDY OF NON-LINEAR POST-SECONDARY MOBILITY
}

\author{
REANA MAIER \\ MCMASTER UNIVERSITY \\ KAREN ROBSON \\ MCMASTER UNIVERSITY
}

\begin{abstract}
In this study, we explored experiences of Ontario students who engaged in a university-to-college (UTC) transfer. Data was collected through qualitative interviews with 20 participants who began their post-secondary journey in a university program but left before completing it and subsequently pursued a college program. We focused on motivations for transfer, the decision-making process, and participants' reflections on their decision to transfer. Framing the transfer decision within a model of educational decision-making that draws on Rational Action Theory (RAT) and Bourdieu's habitus, we argue that motivations for leaving university were distinct from, though related to, motivations for pursuing college. Reasons for leaving university were clustered around three themes: academic struggles, mental/physical health/special education need struggles, and future prospects. These were highly interconnected and characterized by difficulties, from mild to severe, coping with university. Motivations for pursuing college were more practical, relating to subject interest, college learning environment, location, and future prospects. Both decision processes showed evidence of rational cost-benefit analysis characteristic of RAT, but within a framework of habitus-influenced ideas about success and identity. While most participants reflected positively on their decision to transfer, there were some negative reflections related to a sense of personal failure and/or the negative reactions of others, particularly parents. Personal and external negative reflections were tied to cultural and societal expectations about high achievement and perceptions of university education as superior to college education, again showing the influence of habitus. We conclude with policy recommendations.

Keywords: post-secondary education, post-secondary transfer, Ontario, education policy
\end{abstract}

\section{Résumé}

Dans cette étude, nous explorons les expériences d'étudiants en Ontario qui sont passés d'une université à un collège. Les données proviennent d'entretiens qualitatifs avec 20 participants qui ont commencé leur éducation postsecondaire dans un programme universitaire mais ne l'ont pas terminé, et qui ont ensuite poursuivi un cursus au collège. Nous nous sommes concentrés sur les raisons du transfert, le processus de prise de décision, et les réflexions des participants quant à leur décision. En considérant la décision du transfert selon un modèle de prise de décision éducative qui s'appuie sur la théorie de l'action rationnelle (RAT) et l'habitus de Bourdieu, nous soutenons que les raisons de quitter l'université sont distinctes mais semblables aux raisons de poursuivre une éducation au collège. Les raisons de quitter l'université sont groupées autour de trois thèmes : les difficultés scolaires, les difficultés mentales/physiques ou besoins spéciaux, et les possibilités futures. Ces raisons sont très interconnectées et se caractérisent par une difficulté, moyenne ou sévère, à gérer une formation universitaire. Les raisons de poursuivre une formation au collège sont plus pragmatiques, et concernent l'intérêt à l'égard du sujet d'études, l'environnement d'apprentissage, le lieu, et les occasions futures. Dans les deux cas, le processus de décision démontre une analyse rationnelle du coût et des avantages de chaque option, ce qui est caractéristique de la RAT, mais cela dans le cadre de certaines conceptions du succès et de l'identité influencées par l'habitus. Tandis que la plupart des participants ont une opinion positive de leur décision, certains ont des réflexions négatives provenant d'un sentiment d'échec personnel et/ou des réactions négatives d'autres personnes, en particulier leurs parents. Les réflexions négatives personnelles et externes sont liées aux attentes culturelles et sociétales concernant la réussite et au sentiment qu'une éducation universitaire est supérieure à une éducation au collège, démontrant à nouveau l'influence de l'habitus. Nous concluons en recommandant des stratégies en matière de politiques.

Mots-clés : enseignement postsecondaire, passage de l'université au collégial, Ontario, politique éducative 


\section{Introduction}

Direct entry from high school into either a university degree or a college diploma program is the most common post-secondary education (PSE) pathway for Ontario's students, often referred to as a linear or traditional pathway. Over the past few decades, however, there has been an increase in the number of students taking non-linear or non-traditional pathways through PSE, including transfers within and between post-secondary institutions. According to Statistics Canada's National Graduates Survey 2013, over 30\% of both college and bachelors program graduates had previously completed some other form of PSE (Ferguson \& Wang, 2014).

The majority of Canadian research on post-secondary transfer focuses on college-to-university (CTU) pathways and reasons for engaging in this type of transfer are therefore well established (Durham College, 2016). However, movement in the opposite direction, i.e. a university-to-college (UTC) transfer, sometimes referred to as a reverse transfer (Wilson, 2009; Decock \& Janzen, 2015), has received little attention, particularly in cases where the transfer happens before completion of the university program, and, as a result, we know far less about the motivations for this PSE pathway. Available evidence suggests that UTC transfers are on the rise in Ontario (Usher \& Jarvey, 2012; Robson, Brown, Maier, \& Ranjbar, 2016), though Wilson (2009) noted that it is difficult to get an accurate idea of the extent of this growth. Data sources are scattered and difficult to link with other measures of interest (Kerr, McCloy, \& Liu, 2010).

This paper explores the motivations and reflections of 20 students who engaged in a UTC transfer before completing their university program. We found that UTC transfers, unlike CTU transfers, were unplanned and that motivations for leaving university and motivations for pursuing college were separate. Using an education decision-making model that draws on Rational Action Theory and Bourdieu's habitus, we show how these students' navigation through the PSE landscape was influenced by rational cost-benefit analysis type thinking, but within the parameters of personal, familial, and cultural ideas of identity and success that privileged university over college. The strength and pervasiveness of these ideas sometimes led participants to behave in counter-productive or even unhealthy ways before reassessing their position and choosing an alternate course.

\section{Theoretical Framework - Rational Action Theory and Bourdieu's Habitus}

Rational Action Theory (RAT) models of decision-making centre around cost-benefit analysis, in which subjects consider their decisions in terms of the potential likely positive and negative inputs and outputs of each option and choose the option which has the greatest benefit for the lowest cost in the context of a specified goal (Thompson, 2016). This framework for studying educational decision-making is usually associated with economics-influenced quantitative approaches and the explanation of persistent inequalities in educational attainment, often related to class measures (Becker \& Hecken, 2009; Breen \& Goldthorpe, 1997; Stocké, 2007).

Models of decision-making that follow the work of Bourdieu (1977), on the other hand, centre around his concept of habitus, the dispositions, values, and attitudes that are formed by one's social class. Decisions are a reflection of the sphere in which one was raised and are imbued with culturally-bounded ideas of what is positive and negative, rather than dispassionate calculation in the strict utilitarian or economic sense. Bourdieu's work is used widely in education research, also often in regards to the persistence of educational disadvantage and its relationship to class (Edgerton \& Roberts, 2014; Reay, David, \& Ball, 2001; Bodovski, 2009).

Glaesser and Cooper (2014) argue that though these two theories are often viewed as providing conflicting accounts of decision-making, they can be brought together to provide a more flexible and sophisticated account of this process that more accurately reflects reality. According to this model, actors do often make decisions in a rational way according to cost-benefit analysis, but their habitus shapes conceptions of costs, benefits, and appropriate goals. Bringing these two accounts together allows individuals agency but gives due consideration to the effects of social structures, helping to explain the sometimes apparent irrationality of individual actions.

\section{Literature Review}

The profile of students with previous university experience entering college programs is somewhat different than those who transfer from college to university, though data and research on this group is limited and 
often comes from an American context. UTC transfer students are more likely to be over 25 years old, and they tend to enroll in narrow and applied (as opposed to general or preparatory) courses (Ontario Council on Articulation and Transfer [ONCAT], 2013). Research from the United States has found that UTC transfer is also more commonly observed among students from low socioeconomic status (SES) backgrounds compared to those from advantaged backgrounds (Goldrick-Rab \& Pfeffer, 2009), a finding supported in the Canadian context by a study of Toronto District School Board (TDSB) students and their PSE pathways (Robson et al., 2016). This could be partly due to the comparatively lower cost of college programs. Goldrick-Rab and Pfeffer (2009) also attributed this finding to the poorer academic performance of low SES students, which they link to lower levels of parental educational attainment.

The literature addressing the motivations for UTC transfer is very sparse, and much of what does exist focuses on those who enter college after having graduated from university and again is based on US data. By far the most commonly reported motivations for UTC transfer include concerns around workforce entry, with students drawn to the practical experience and flexibility offered by college programs (Kerr et al., 2010; LeBard, 1999; Decock \& Janzen, 2015). Other UTC transfer motivations present in the literature, though not as prominent as improved career opportunities, include academic failure in university (Decock \& Janzen, 2015; Hagedorn \& Castro, 1999; LeBard, 1999), emotional reasons, such as homesickness, immaturity, substance abuse, difficulty adjusting to university life (Hagedorn \& Castro, 1999; Mitra, 2018), and financial reasons, as college usually costs less (sometimes substantially less) than university (Usher \& Jarvey, 2012; Hagedorn \& Castro, 1999; LeBard, 1999). It is important to note, however, that in the vast majority of UTC research, those who transfer before and after completing university degrees are often lumped together in UTC transfer studies, making it unclear whether their motivations are the same.

There has been little investigation into the academic success or persistence of mid-program UTC transfer students. Much of the evidence available about the outcomes of transfer students has been limited to CTU transfers, and their success has been mixed (Stewart \& Martinello, 2012; ONCAT, 2013; Shook, Norman, \& Guyatt, 2016). What little evidence we do have about UTC transfer students suggests that they do not tend to struggle academically post-transfer. A study of transfer students between Algonquin College and the University of Ottawa (both directions) showed that the CTU transfers were more likely to leave compared to direct entry high school students, but the UTC transfers showed no difference in persistence rates to their direct entry counterparts (Finnie et al., 2012). A study of transfer students between York University and Seneca College (in both directions) between 2000 and 2012 found that UTC students fared better post-transfer in terms of GPA (Smith, Decock, Lin, Sidhu, \& McCloy, 2016).

\section{Methodology and Data}

Previous research by the authors on trends in PSE pathways for TDSB students indicated that UTC transfers were increasing, and the analysis showed that these students tended to be from lower SES backgrounds (Robson et al., 2016). However, the nature of the data in that study could not offer any insight as to why students were leaving university and pursuing college instead. Moreover, other research on UTC transfers did not differentiate between graduates and non-graduates. To explore the motivations and circumstances behind decisions to engage in a mid-program UTC transfer, we undertook an exploratory qualitative study focused on the following research questions: 1) What factors led to the decision to UTC transfer before completing university?; and 2) What were participants' experiences of and reflections on that decision, particularly in regard to any barriers encountered? We theorized that mid-program UTC transfers would be prompted by a wider array of motivations than career boost and would likely feature some kind of struggle with university life, in particular the high cost of tuition.

We conducted 20 in-depth interviews with purposively sampled participants who met the criteria of having been enrolled in an Ontario university program and then transferring to an Ontario college program without completing university. The study was open to those who were current students or had already graduated from a college program in southern Ontario, and there was no restriction in terms of the length of time in between the participants' university program and their college program. Indeed, we hoped we would get a range of possible pathways, some including time off in between programs and some not. Participants were invited to a semi-structured individual interview of approximately one hour. 


\section{Findings}

\section{Sample Demographics}

The demographic characteristics of our sample are listed in the Table 1. The participants were balanced in terms of gender and were from a variety of racial and migrant status backgrounds, which is reflective of Toronto's diverse population.

Participants' high school graduation year ranged from 2004 to 2016, and all participants reported having average high school grades of 70 and above, with 16 out of 20 reporting grades above 80 . In addition, 17 out of 20 participants had at least one parent who had completed either a college or a university program. Four participants reported being identified as having a Special Education Need. ${ }^{1}$

Table 1. Sample demographics

\section{Gender}

Male

10

Female

10

Age

24.4 (range 20-32)

Racial Background

White

Black

East Asian

2

South/Southeast Asian $\quad 4$

Middle Eastern 1

Mixed

\section{Born Outside Canada}

Participant

Not participant, but at least one parent

\section{Parents' Education}

At least one parent completed university

At least one parent completed college

4

No post-secondary/don't know 10 10

3


transfers between different programs within university (sometimes by choice, sometimes because of academic probation requirements), hiatuses during and after university to work or deal with health or personal issues, remedial courses to improve chances of admission to certain programs, and attempts at and sometimes completions of multiple college programs. Some of them also had plans for further PSE after completing the program they were in (or had recently finished) at the time of the interview.

The majority of our participants (15) remained within the same or a similar subject area pre- and post-transfer. For example, one participant transferred from a university engineering degree program to a college engineering degree program, and one transferred from a nursing degree to a nursing diploma. There were several instances of transfers from general sciences or computer science degree programs to computer or technology-related college diplomas, such as programming or medical equipment technicians. Three students who were in university social sciences transferred to social service work programs in college. We did have five participants who changed subjects completely from pre- to post-transfer, switching from STEM to non-STEM subjects or vice versa, for example, general sciences to accounting or business administration or social sciences to software development.

The amount of time participants spent attempting a university program before leaving ranged from one year to seven years, with an average between two and two and a half years. Eight participants changed programs within university, sometimes by choice due to lack of subject interest, but for three participants, the university forced the program switch due to poor academic performance. Two participants spent multiple years in this pattern of poor academic performance in their original program, followed by academic probation in another program, reentry back to the original program, poor academic performance, academic probation, and so on. Another participant was not forced to change programs because of poor academic performance, but also fell into a pattern of failing and having to repeat courses, spending years in university while making little progress toward the completion of a degree.

\section{Transfer Motivations}

Consistent with previous studies in the area, participants rarely had a single reason behind their decision to trans- fer. Far more often, there were multiple reasons having to do with their situations at the time (both personally and academically), future prospects, money, and parental and self-expectations. These multiple reasons also tended to be connected to each other, reinforcing (or exacerbating) each other (Hagedorn \& Castro, 1999; Mitra, 2018). However, unlike previous research, we found it necessary to make a distinction between deciding to leave university and deciding to enter college, because motivations for each, though often connected, only partially overlapped. Examining the decisions separately helped us to pinpoint what makes the mid-program UTC transfer unique in the transfer landscape - it happened almost exclusively in response to something not going according to plan. As such, we will first address motivations for leaving university, which clustered around three themes: academic struggles, physical/mental health struggles, and future concerns. We then discuss reasons for choosing to pursue college.

\section{Leaving university - academic struggles}

There were a number of motivations for leaving university that clustered around the theme of academic struggles. Several participants talked about how unprepared high school had left them for university study. The majority of our participants had been successful in high school, however, participants also commented on the relatively low effort it took to achieve high marks there. They found university courses a struggle in comparison. As one participant put it, "[w]ith university, I can't coast like I could in high school. You have to actually do the work otherwise you're going to fall behind" (ONCAT18-13).

The majority of our participants found that they were struggling with a combination of more difficult material, and also, perhaps more importantly, an environment in which self-motivation and self-discipline were required in order to be successful. Their courses were more intellectually challenging and the workload in most cases greater than what they had experienced in high school, and many of them were missing the skills that would have helped them cope with this increased demand. While a few participants listed their newfound autonomy as one of the positive aspects of university, others found that this led them into trouble when it came to time management and discovered that the last-minute study and moderate effort that saw them through high school would not be sufficient in university. Twelve participants reported significant academic struggles, including low grades, 
failing courses, being forced to change programs, and, in two cases, one-year academic suspensions from university. Even students who were not experiencing derailing academic struggles were concerned about workloads and fine grades still not being enough to advance to further levels of study, like graduate or medical school.

These academic struggles were exacerbated by a lack of motivation, often fueled by disillusionment with their subject, and resulted in patterns of non-attendance. Because participants were now in an environment in which their attendance was largely unmonitored and grades based on infrequent testing rather than regular assignments, some began to lose motivation to attend class and keep up with readings, particularly if they found they were uninterested in the subject matter or enjoying their studies:

I guess [I was] losing interest in my program ... I was vaguely fascinated by some of the things I was learning in [my major], but the other courses that I was taking, the content just did not appeal to me. I guess academically, intellectually ... It never stimulated my interest (ONCAT18-14).

For about a quarter of our participants, disillusionment with their subject was partially caused by frustration with what they saw as the overly theoretical nature of university learning. Students in both arts programs and STEM programs expressed dissatisfaction with the lack of practical applications for the content they were learning in their courses: "Translating [theoretical knowledge] into application is a skill that is not being taught" (ONCAT18-10).

Throughout these interconnecting issues related to academic struggles was a sense of the university as an indifferent place-indifferent to participants' problems, needs, and their success or failure. One participant said that this was made clear from the very beginning: "Orientation. The guy basically told us that this isn't high school, and if you fail, nobody cares. Those are almost the exact same words" (ONCAT18-13).

Participants felt that this sense of their insignificance was reflected in many aspects of their university experience: class sizes in the hundreds, lack of academic and other kinds of support, professors difficult to reach or simply unavailable, administrative issues and the length of time it took to solve them, sometimes questionable quality of instruction, and inflexibility in scheduling.
This sense of the university as indifferent was problematic in a number of ways, not least because it discouraged our participants from even attempting to seek help. When asked if there was support available to help them through their academic struggles, some participants spoke about the limited availability of help and the difficulty in obtaining it, such as tutoring: "Professors usually were doing their own research so it was hard to get a hold of them. If you were lucky you got the lab TA" (ONCAT18-18); "I would be waiting on answers when the answers no longer matter" (ONCAT18-12). However, some also admitted that they did not know if the university provided support because they did not look: "I don't think I really looked, to be honest" (ONCAT18-12).

\section{Leaving university - physical/mental health/ special education need (SEN) struggles.}

The lack of support and the university as an indifferent place carries through to our second prominent theme: physical/mental health/SEN struggles. While we have separated these from academic struggles for the purposes of this discussion, they were highly intertwined, with difficulties in one area spilling over into the other.

We had four participants who had been identified as having a SEN, and navigating their university's accommodations services proved a tricky task. ONCAT18-03 was able to secure some accommodations at university in the form of extended deadlines, but found his experiences with that office were hit and miss: "It's really who you talk to. If I get somebody who's sympathetic, then they might [be able to help], but if someone's just really caught up in like the bureaucracy, then nope." ONCAT18-07 felt that the university did not do enough to ensure that students knew what services were available, as she was not aware that she could get accommodations for SEN until after almost four years of struggling. The difficulty in securing accommodations and the inconsistency with which those accommodations were honoured unsurprisingly caused these participants to struggle academically and added unnecessary stress to an already demanding environment.

Half of the participants reported mental health struggles that ended up playing a significant role in their decision to leave university. These struggles took a number of forms and ranged from mild to severe, including anxiety, insecurity, inability to concentrate/work, depression, hospitalization, and suicidal thoughts. The scale of the university and its indifference caused many to feel 
isolated and alienated from faculty, staff, and even their peers, another marked difference from high school:

It's a lot of people in one room. It's a little bit overwhelming if you're coming from [a] high school setting of 30 students max to 500 or more students in one classroom . . . I remember sitting in the lecture halls and feeling very uncomfortable (ONCAT18-11).

Whether academic struggles were a cause or a consequence of mental health issues, they created a negative feedback loop that derailed progress through the participants' degree programs. Some expressed frustration with "being stuck," "not getting anywhere," or "hitting a brick wall," particularly those who got into a pattern of failing and repeating courses.

\section{Leaving university - future prospects}

Participants' concerns about the future centered on expected returns on their university degree. Essentially, they did not think that the university program they were pursuing would lead to a viable job. There were some participants who were frustrated with what they saw as the overly theoretical nature of university learning, stemming partly from a desire to be employable once their degree finished. Other participants continued to enjoy their university subjects, but were concerned about the lack of jobs in their field and therefore doubting whether completing their degrees was worthwhile.

\section{Entering college}

After the turmoil and struggle that characterized the participants' decisions to leave university, their reasons for pursuing college were much more positive and straightforward, coming under the general themes of subject interest, college learning environment, location, and future prospects.

\section{Entering college - subject interest}

At the core of the participants' motivations for choosing college was that courses being offered suited their interests. This may seem like a very simple, even banal, observation, but considering the number of participants who reported losing interest in the subject they were studying in university, being interested and even excited about PSE should not be underestimated. It was by far the most common reason for choosing to pursue college. Moreover, because they had spent time in university and, for some, working, they had a better developed sense of their interests and the kind of work they would like to do in the future, or, at least, what they were not interested in doing. As ONCAT18-15 put it when choosing a program to enter, "I was a little bit more decisive."

\section{Entering college - college learning environment}

While subject interest was the most common motivation given for choosing a college program, it was never given as the sole reason. Most of the subjects the participants were interested in studying were also offered at university, but given the negative experience many of them had there, they wanted a different learning environment. Participants were drawn to the smaller class sizes, easier entry requirements, friendlier atmosphere, shorter program lengths, cheaper tuition, and hands-on learning of college programs: "It's very hands-on. There's so much support, like everybody knows you by name. You're not afraid to ask for help. It's [a] very team-oriented environment ... the classes are a lot smaller" (ONCAT18-07). These are in clear contrast to many of the complaints the participants had about the university learning environment. Indeed, while they spoke about university as a shock compared to high school, many participants commented that college was much more like high school, making it an easier transition.

\section{Entering college - location}

Location was the second most cited reason for choosing to go to college. The participants were interested in studying particular subjects in a college learning environment, but they wanted to do so close to home. This is another motive that should not be underestimated, considering how many of the participants struggled with mental health, isolation, and commuting while at university. Being able to live at or near home made sense financially, practically, emotionally and psychologically. ONCAT18-03, who had struggled with serious mental health issues while at university, put it this way:

[T] he major draw about college for me was that I could essentially stay at home and come [to a local college]. It was low risk. I didn't have to look for an apartment away from home and get rid of all my social supports. 


\section{Entering college - future prospects}

Closely connected to the appeal of college learning as "hands-on" and "career-oriented" was the perception that college would be more beneficial to future prospects. Thirteen participants reported a job-related motivation as a reason for choosing college. They felt that a college diploma would make it either easier to get a job after graduating or would lead to more stable job opportunities in the future. The opportunity for future work opportunities was, for 8 participants, concentrated in the inclusion of co-op or job placements in their programs. Several more participants also listed co-op or job placements as one of the positives of college education in a later section of the interview, though they did not initially cite it as a motivation for choosing college.

Usher \& Jarvey's (2012) study of students who transferred into college (either from university or other colleges) found very few respondents who cited dissatisfaction or a negative experience as a reason for transferring, which, they argued, suggested that transfers have more to do with pull factors than push factors. Our findings, however, indicated that push factors were highly relevant for mid-program UTC transfer students. Many of the participants had negative experiences at university and expressed a great deal of dissatisfaction with the university environment. In other words, for many of our participants, while their reasons for leaving university were related to their reasons for pursuing college, the pull factors of college became relevant only after the push factors of negative university experiences and trying personal circumstances forced them to reevaluate their plans.

\section{Transfer Reflections}

On the whole, participants reported very positively on their transfer, with 18 out of 20 explicitly stating that it was a good decision. ONCAT18-01 summed up the feelings of the majority of the participants when she said, "I think it was a good decision to come here, and I think it was kind of nice to get a fresh start." Like several of the others, she was enjoying her college program much more than she had enjoyed university and felt she had been able to re-establish her work ethic. The improved performance of our participants supports the (albeit scant) evidence in the research literature that UTC transfer students tend to fare well post-transfer. Nine participants were not only happy with their decision to leave university and go to college, but they expressed a wish to have transferred earlier, or even to have skipped university altogether and gone to college straight out of high school: "My only regret is that I didn't do it sooner" (ONCAT18-15).

For ONCAT18-03 and three other participants, their time in college had not only seen academic improvement, it was also helpful in terms of recovering from some of the mental and physical health struggles they experienced in university. His turnaround since leaving university, where he experienced severe mental health struggles, was significantly boosted by his college experience, which he felt had given him purpose:

[This college program] is probably the best that could have happened to me because there was a time when I even questioned if I could work again because of my diagnosis. And to be able to see myself gradually inch forward and get to a point where l'm now working in a field that's not food service, like I actually have qualifications now, it's incredible. I feel immensely proud.

Despite the overall positive nature of our participants' reflections, there were some lingering regrets and doubts expressed by many, though they did not cause any of them to regret wholesale their decision. Most often, regrets stemmed from two causes: a sense of personal failure and disappointing others. Six participants felt that leaving university before graduating reflected badly on them and left them with a sense of failure, especially in the period leading up to and immediately after their departure from university:

I started to think about what made me feel bad for not finishing that program, and it was essentially that I felt like I had failed. I felt like I had just, I reached my limit, I tried to push against it, and I couldn't do it (ONCAT18-03).

The other prominent source of regret or ambivalence came from the reactions of others to their decision. The vast majority of participants reported that, at the time of the interview, their family and friends were supportive of the participants' choices and were happy to see them succeeding in college. Just over half of participants also reported, however, that approval of their decision was not universal, that some significant people in their lives did not support transfer, at least initially. This appeared 
to be largely due to cultural and societal expectations surrounding high achievement, particularly as enforced by parents, and perceptions of university education as superior to college education. Indeed, participants spoke at length in this section and other sections of the interview about their own and others' biases in favour of university over college. Four participants linked this bias toward university to race, culture, and immigrant status:

Especially I think in South Asian communities, when they immigrated over here, they worked tough jobs, and I know all my cousins, they kind of have the same experience where they ... don't even talk about college. College is kind of looked down upon. So, it's university, that's the just the natural progression (ONCAT18-12).

Of the participants who reported disapproval from family or friends, almost all identified as either visible minorities or first or second-generation immigrants, or both. These participants' experiences support other Canadian education research, showing that recent immigrants tend to have higher expectations for their lives and of their children (Kaushik \& Drolet, 2018; Areepattamannil \& Lee, 2014), and that certain ethno-racial groups, particularly Asian groups, have higher academic achievements than peers from other groups (Robson, Brown, \& Anisef, 2016), which some researchers have linked to high parental expectations (Yau, O'Reilley, Roselen, \& Archer, 2011; Yau, Roselen, \& Archer, 2015). It is perhaps not surprising, then, that some participants were met with resistance when they decided to leave university and pursue college instead.

\section{Discussion: Habitus-bounded Rationality in Mid-program UTC Decisions}

Though the decision to engage in a mid-program UTC transfer was characterized by struggle as we expected, the nature of the struggles, the length of time participants spent struggling before leaving university, and the necessity of separating decisions to leave university from decisions to pursue college were unexpected findings. We argue that these findings demonstrate the dynamic relationship between rationality and habitus in educational decision-making, with cost-benefit analysis drawing on ideas about costs, benefits, options, goals, and success that have been shaped by the participants' habitus, specifically the disposition towards PSE, with university education as superior to college education.

First, we consider the decision to leave university. Because this decision was overwhelmingly rooted in struggle of one sort or another, it was rational for our participants to cease their university study and pursue some other avenue. What is striking, however, and what showed the powerful disposition toward university education shaped by their habitus, was the length of time it took the participants to make that decision, the sometimes destructive nature of the struggles they endured during that period, and the regrets they and some of their families expressed over leaving university. Problems with the cost of university, which we expected would constitute a prominent obstacle, were mentioned by surprisingly few of our participants and did not emerge as a significant theme.

Instead, it was the fear of failure and the seeming inability to consider alternative pathways that proved more troublesome. Participants noted again and again their and others' conception of university as the appropriate route to a successful future, success usually being framed in terms of economic and occupational prospects that either improved or maintained their socio-economic status. Indeed, when participants spoke about their decision to pursue university in the first place, there was little actual decision-making involved, outside of what subject they would study. As far as they were concerned, the cost-benefit analysis had already been done and their pathway obvious: “University wasn't even much of a decision at the time ... It was kind of the norm. Of course I'm going to university" (ONCAT18-09); "I never took a college course before, so ... why would I go to college? It never occurred to me at that time" (ONCAT18-14). College, from the participants' perspective, would have been an almost irrational decision. Parental/familial and cultural influence was key in this for many of them, particularly for those from certain backgrounds, as noted in the previous section. Only one participant considered anything other than university after high school, but his parents pushed him to go to university anyway.

Even when they began to struggle in university, many of the participants continued to view university as the only viable way forward:

I didn't feel like there were any other options for me, 
which is why I basically stuck around in that program for nearly five years, trying to get through it . . . I was still in the mentality of the [university] is the best [option] out there, and if I don't do this, then I'm a failure (ONCAT18-08).

We could see from the findings how habitus restricted the participants' ideas about goals, success, and the costs of these, such that remaining in university despite its toll seemed to them to be a rational decision. The point at which the costs outweighed the benefits was different for each of our participants, but the critical importance of university to ideas of success shaped the boundaries of that equation for all of them.

The next key decision-making process came after the participants left university. Here, we could see what were more straightforward examples of cost-benefit analysis and rational decision-making, though we argue one can still see the influence of habitus. The decision to pursue college showed a great deal more consideration than initial decisions to pursue university and, to a greater or lesser extent, serious reflection on university experiences so as not to repeat the struggles that characterized them. There were, however, some unchanged underlying assumptions about education and success that influenced this decision, namely that a stable, skilled, and high-paying occupation was still a primary marker of success and that being in some form of post-secondary education was better than not being in it at all. In addition, a few of our participants were impatient to finish with education, because they felt they were behind where others their age were on their life pathways and had very specific ideas about what they should have accomplished by now:

I'm 27, I'm still not done my education, you know? I work at a [retail store] ... [Former classmates] are finished the diploma program, and they're working, and they're moving on with their lives. At the end of the day, they're making money, and I'm not (ONCAT18-08).

\section{Policy Considerations and Recom- mendations for Future Research}

CTU transfers have been the more visible transfer type in the PSE landscape, with college often seen as a step- ping-stone to university, reflecting the dominant narrative of university education's superiority. Indeed, there are programs that are designed with such a transfer built in, known as articulated agreements or bridging programs. Our study suggests that mid-program UTC transfers are not planned in this way, either by individual students or as part of any institution's program design, and are, in fact, characterized by struggle and difficult decision-making processes, making this a transfer population with distinct needs that are going largely unrecognized. In light of our findings, we suggest the following policy initiatives, recognizing that such recommendations are a somewhat tricky proposition in Ontario, because each institution has jurisdiction over its own policy and practices.

\section{Conduct exit surveys}

Exit interviews are common in the world of employment, but have not yet, to our knowledge, been widely implemented with students leaving post-secondary institutions. Following the suggestion of one of our participants, we recommend that universities conduct exit surveys with leaving students (interviews being too cumbersome for the number of students who drop out), with especial attention to those who leave mid-program and their reasons for doing so. These surveys can be used to evaluate programs and support services, identify problem areas, and enrich the pool of research data available in the PSE mobility arena.

\section{Aim information at high school students}

Information about non-linear post-secondary pathways and transfer should be aimed at high school students. Our study shows that high school students in Ontario can be better informed about their post-secondary options and about the learning environments of both college and university. Moreover, they should be made aware of the potential for non-linear pathways and post-secondary mobility. Transfer should become a more frequent feature of PSE pathway discussions from high school on, as it may well be a feature of their post-secondary journey.

\section{Abandon the use of reverse transfer and its underlying mentality.}

The phrase reverse transfer implies that CTU transfer is normal and correct, and UTC transfer students are going the wrong direction. Its use should be abandoned in edu- 
cation practice or research. The perception of university education as superior to college education was strongly noted by our participants, both in their own internalized thinking and in the reactions of those around them. This contributed to some of the resistance many encountered in even contemplating a move out of university, despite the intense and prolonged nature of the struggles they experienced there. As mobility in all directions in the post-secondary landscape becomes more common, we believe it is important to describe such movement with neutral language (simply university to college transfer) or even language that recognizes the resilience and grit of students who persist in this manner (Mitra, 2018).

\section{Improve transfer data infrastructure}

We join other researchers across Ontario who demand a more centralized, comprehensive, and open data infrastructure in education (Gallagher-MacKay, 2017). At the time of writing, it is difficult if not impossible to get a complete picture of PSE mobility in Ontario, because, despite every Ontario student having an anonymized identifier that follows them throughout their entire educational career, there is no central database available to researchers that would allow us to follow progress through the education system, particularly at the post-secondary level. In order to better track and study PSE pathways, researchers need access to data on demographic characteristics of students, enrollment, persistence, academic performance, completion, satisfaction, and labour force entry. Large-scale datasets can help refine and support qualitative studies such as this one, providing a better understanding of the directions and influences that are shaping the PSE pathways of Ontario students.

\section{Future Research}

This study helped to identify the decision-making processes involved in an understudied area of PSE mobility, noting the influence of habitus-shaped ideas of success on the analysis of available options, sometimes to the detriment of the participants. However, it raises a number of questions and directions for future research, both empirical and philosophical. How do high school students evaluate their post-secondary options, and what are the factors that influence their thinking? How do Ontario students compare with those from other parts of Canada and internationally in terms of PSE mobility? What is the appropriate balance for universities to strike between supporting students who are struggling with university life and maintaining academic standards? What are the consequences of aggressively promoting a university for all agenda for both college and university education, as well as to those for whom university may not be the best option for their goals and situation? The first two questions call for the expansion of data infrastructure we outlined above and for more qualitative work around educational decision-making. The last two questions also call for empirical evidence, but also for policy analysis and philosophical consideration from a macro perspective about the nature and purpose of post-secondary education.

\section{Acknowledgements}

The authors would like to acknowledge the support of the Ontario Council on Articulation and Transfer, whose funding made this research possible.

\section{References}

Areepattamannil, S., \& Lee, D. H. L. (2014). Linking immigrant parents' educational expectations and aspirations to their children's school performance. Journal of Genetic Psychology, 175(1), 51-57. https://doi.org/10.1080/00221325.2013.799061

Becker, R., \& Hecken, A. E. (2009). Higher education or vocational training? An empirical test of the rational action model of educational choices suggested by Breen and Goldthorpe and Esser. Acta Sociologica, 52(1), 25-45. https://doi. org/10.1177/0001699308100632

Bodovski, K. (2009). Parental practices and educational achievement: Social class, race, and habitus. British Journal of Sociology of Education, 31(2), 139-156. https://doi.org/10.1080.01425690903539024

Bourdieu, P. (1977). Outline of a theory of practice. Cambridge, England: Cambridge University Press.

Breen, R., \& Goldthorpe, J. H. (1997). Explaining educational differentials: Towards a formal rational action theory. Rationality and Society, 9(3), 275-305. https://doi.org/10.1177/104346397009003002

Decock, H., \& Janzen, K. (2015). A qualitative study of the York-Seneca transfer experience. Retrieved from 
ONCAT database: https://oncat.ca/sites/default/files/ research/2013-09-Executive-Summary-Seneca-College-Qualitative-Study-of-the-York-Seneca-Transfer-Experience.pdf

Durham College. (2016). Credit where credit is due: Understanding the credit transfer experience at Ontario colleges. Retrieved from ONCAT database: https:// oncat.ca/sites/default/files/research/2014-31-FinalReport-Credit-where-credit-is-due-understandingcredit-transfer-in-Ontario-Colleges.pdf

Edgerton, J. D., \& Roberts, L. W. (2014). Cultural capital or habitus? Bourdieu and beyond in the explanation of enduring educational inequality. Theory and Research in Education, 12(2), 193-220. https://doi. org/10.1177/14778787514530231

Ferguson, S., \& Wang, S. (2014). Graduating in Canada: profile, labour market outcomes and student debt of the class of 2009-2010. Retrieved April 14, 2020 from Statistics Canada website: https://www150. statcan.gc.ca/n1/pub/81-595-m/81-595-m2014101eng.pdf

Finnie, R., Pavlic, D., Childs, S., Diaz, V. E., Mercier, P., \& Lewrey, W. (2012). Transfer student persistence at Algonquin College and University of Ottawa. Retrieved from ONCAT database: https://oncat.cal sites/default/files/media-files/2012-14-final-reporttransfer-students-at-algonquin-college-and-the-university-of-ottawa 0.pdf

Gallagher-MacKay, K. (2017). Data infrastructure for studying equity of access to postsecondary education in Ontario. Retrieved from HEQCO website: http://www.heqco.ca/SiteCollectionDocuments/ FINAL\%20Data\%20Infrastructure.pdf

Glaesser, J., \& Cooper, B. (2014). Using rational action theory and Bourdieu's habitus theory together to account for educational decision-making in England and Germany. Sociology, 48(3), 463-481. https:/l doi.org/10.1177/0038038513490352

Goldrick-Rab, S., \& Pfeffer, F. T. (2009). Beyond access: Explaining socioeconomic differences in college transfer. Sociology of Education, 82(2), 101-125. https://doi.org/10.1177/003804070908200201

Hagedorn, L. S., \& Castro, C. R. (1999). Paradoxes: Cal- ifornia's experience with reverse transfer students. New Directions for Community Colleges, 1999(106), 15-26. https://doi.org/10.1002/cc.10602

Kaushik, V., \& Drolet, J. (2018). Settlement and integration needs of skilled immigrants in Canada. Social Sciences, 7(5), 1-14. https://doi.org/10.3390/socsci7050076

Kerr, A., McCloy, U., \& Liu, S. (2010). Forging pathways: students who transfer between Ontario Colleges and Universities. Retrieved from HEQCO website: http:/l www.heqco.ca/SiteCollectionDocuments/ForgingPathwaysENG.pdf

LeBard, C. (1999). Sources and information on the scope and impact of reverse transfers. In B. Townsend (Ed.), Understanding the impact of reverse transfer students on community colleges ( $\mathrm{pp}$. 85-92). San Francisco, CA: Jossey-Bass.

Mitra, B. (2018). Ready for a new start? A case study of students who transfer from four-year institutions to community college: Experiences and learned navigational strategies (Doctoral dissertation). New York, NY: Teachers College, Columbia University.

Ontario Council on Articulation and Transfer (ONCAT). (2013). Summary of ONCAT-funded pathways and transfer research. Retrieved from ONCAT database: https://oncat.ca/sites/default/files/inline-images/oncat-research-summary-2013-english.pdf

Reay, D., David, M., \& Ball, S. (2001). Making a difference? Institutional habituses and higher education choice. Sociological Research Online, 5(4), 14-25. https://doi.org/10.5153/sro.548

Robson, K., Brown, R. S., \& Anisef, P. (2016). Identifying the complexity of barriers faced by marginalized youth in transition to postsecondary education in Ontario. In W. Lehmann (Ed.), Education and society: Canadian perspectives (pp. 51-65). London, England: Oxford University Press.

Robson, K., Brown, R. S., Maier, R., \& Ranjbar, M. (2016). Unraveling the knot: Understanding the diverse postsecondary pathways of Toronto high school students. Retrieved from ONCAT database: https://oncat.ca/en/projects/unraveling-knot-understanding-diverse-postsecondary-pathways-toron- 
to-high-school-students

Shook, C., Norman, C., \& Guyatt, J. (2016). Assessing determinants of academic success for college to university transfer in the diploma to degree program: Executive Summary. Retrieved from ONCAT database: $h$ htps://oncat.ca/sites/default/files/research/2015-07-Executive-Summary-The-Governing-Council-of-UofT-Assessing-Determinants-of-Academic-Success-for-College-to-University-Transfer.pdf

Smith, R., Decock, H., Lin, S., Sidhu, R., \& McCloy, U. (2016). Transfer pathways in postsecondary education: York University and Seneca College as a case study. Retrieved from HEQCO website: http://www. heqco.ca/en-ca/Research/ResPub/Pages/Transfer-Pathways-in-Postsecondary-Education-York-University-and-Seneca-College-as-a-Case-Study-.aspx

Stewart, J., \& Martinello, F. (2012). Transfer students in Ontario: How are they faring? Retrieved from ONCAT database: https://www.oncat.ca/sites/default/ files/research/2012-1-Brock-Transfer-students-inOntario-how-are-they-faring.pdf

Stocké, V. (2007). Explaining educational decision and effects of families' social class position: An empirical test of the Breen-Goldthorpe model of educational attainment. European Sociological Review, 23(4), 505-519. https://doi.org/10.1093/esr/jcm014

Thompson, R. (2016). Explaining inequality? Rational action theories of educational decision making. In A. Mountford-Zimdars \& N. Harrison (Eds.), Access to higher education: Theoretical perspectives and contemporary challenges (pp. 67-84). New York, NY: Routledge.

Usher, A., \& Jarvey, P. (2012). Student experiences in credit transfer at Ontario colleges: Final report. Retrieved from ONCAT database: https://oncat.cal sites/default/files/media-files/2012-03 final report en student experiences in credit transfer at ontario colleges.pdf

Wilson, D. N. (2009). Reverse transfer constraints upon planning post secondary programs. In R. L. Raby \& E. J. Valeau (Eds.), Community college models: Globalization and higher education reform (pp. 401-416). New York, NY: Springer.
Yau, M., O'Reilly, J., Roselen, L., \& Archer, B. (2001). Census portraits: Understanding our students' ethno-racial backgrounds: East Asian students. Toronto, ON: Toronto District School Board. Retrieved from https://www.tdsb.on.ca/Portals/research/docs/ reports/PortraitsEastAsian.pdf

Yau, M., Roselen, L., \& Archer, B. (2015). Census portraits: Understanding our students' backgrounds: South Asian students. Toronto, ON: Toronto District School Board. Retrieved from https://www.tdsb. on.ca/Portals/research/docs/reports/PortraitsSouthAsian.pdf

\section{Contact Information}

Reana Maierr rgmaier1@gmail.com

\section{Notes}

1 On the demographic sheet completed at the time of interview, participants were asked to indicate (yes or no) if they had "ever been identified as having a special education need or accommodation, including an Individual Education Plan." For the four participants who indicated 'yes', the identification was made either by their high school or by accommodation services at university. We did not ask participants to disclose the nature of their SEN as it was not necessary for the purposes of the study. 